\title{
The influence of cronyism on entrepreneurial resource acquisition
}

\author{
Junfan $\mathrm{Yu}^{1}$ - Saskia De Klerk ${ }^{2}$ - Michael Hess ${ }^{1}$
}

Accepted: 5 April 2021/ Published online: 19 July 2021

(C) The Author(s) 2021

\begin{abstract}
This research focuses on how entrepreneurs utilize cronyism to acquire resources. A case study method allowed us to explore three firms in the private property development industry in China. These firms uniquely cultivated cronyism and achieved distinctly different outcomes. Our findings highlight Chinese entrepreneurs in start-up ventures and later-stage enterprises employ cronyism. The underlying rationale for using cronyism have common and heterogeneous motivations. The similarity and distinguishing rationale also apply to the impact of cronyism. We also find two contingency working mechanisms for cronyism: entrepreneurial characteristics and a staged model for cronyism. With the firm's growth, cronyism remains important, but firms with more community involvement outperform others. This research contributes to the theory on strategic network utilization for resource acquisition during entrepreneurial development stages. We investigate how entrepreneurial strategies can assist in adapting to the "rules of the game" while utilizing resources within the set contextual constraints.
\end{abstract}

Keywords Cronyism - China's private enterprises - Guanxi - Informal personal networks · Strategic network utilization, entrepreneurship

While entrepreneurship has contributed significantly to China's economic development (Guo \& Miller, 2010), networks have been important to entrepreneurial growth (Furlan

Junfan Yu

junfan.yu@unsw.edu.au

Saskia De Klerk

sdeklerk@usc.edu.au

Michael Hess

m.hess@adfa.edu.au

1 School of Business, University of New South Wales, Canberra, ACT, Australia

2 School of Business, University of the Sunshine Coast, Sippy Downs, QLD, Australia 
et al., 2014; Lee \& Tsang, 2001). Entrepreneurial resource acquisition is deemed to be vital, complex, and challenging for enterprises (Shane, 2003). When formal institutions (e.g. written constitutions, laws, regulations, and policies) are absent or ineffective, as in the case of China, the success of entrepreneurial activities relates closely to using informal networks, guanxi, and, in some cases, cronyism (Guo \& Miller, 2010; Luo et al., 2012; Meuer \& Krug, 2011). Research finds informal networks facilitate acquiring entrepreneurial resources, including financial, human, and physical capital (Zane \& DeCarolis, 2016).

Cronyism is the practice of offering favoritism based on long-term social networks, including "kindship, friendship, ethnicity, religion, school, workplace, mutual interest, and other grouping categories" (Andrews et al., 2019; Khatri et al., 2016: 35). Therefore, cronyism between resource owners and entrepreneurs is not limited to the enterprise-government relationship but also superior-subordinate and family relationships. Cronyism and informal networks are described as "rent-seeking" activities embedded in cultural orientation (Mitchell et al., 2019). The worldview of some cultures to build relationships rather than focus on short-term economic transactions is at the heart of how cultures view cronyism and nepotism as being part of business (Hudson \& Claasen, 2017).

Existing research focuses on the impacts of cronyism and finds mixed outcomes depending on the context (Leung et al., 2008; Salter, 2014); however, little attention has been paid to how enterprises use cronyism. The existence of cronyism and its importance is portrayed mostly as an ethical or legal issue or a moral scandal (Krug \& Hendrischke, 2003). For example, research shows cronyism can harm firm development (Enderwick, 2005; Kang, 2003; Khatri et al., 2003) through producing entry barriers, skewing resource allocation, restricting specialization, restraining competition, and decreasing product quality (Begley et al., 2010). Therefore, most researchers conclude that cronyism should be eliminated in most circumstances (Enderwick, 2005; Khatri et al., 2003).

This lack of research on the "process" of how cronyism is practiced is largely related to the differences in context: while cronyism is difficult to measure to complete accuracy, unlike corruption, it is not illegal; cronyism is thus even harder to define and measure as no court or indictment records exist (Smith \& Sutter, 2012). For countries in economic transition, it is a mistake to equate cronyism based on particularistic ethics to corrupt cronyism ( $\mathrm{Li}, 2009)$. Cronyism is argued to be more acceptable in high-context cultures and based more on building trust (Leung \& Barnes, 2020). It is also interpreted according to culture and previous experiences. The industry or the community in which this takes place also influences how this is widely implemented and accepted. Therefore, we do not dispute that cronyism practice exists, but the focus is rather on what these networks are used for.

In China, President Xi Jinping advocated qinqing in dealing with the practice of cronyism, especially in managing the government-enterprise relationship (Xi, 2018). According to President $\mathrm{Xi}$, qin means keeping harmony within the family, caring about family members, spending more time in taking care of the development of private enterprises and entrepreneurs; while qing means distinguishing private from public, avoiding misusing authority to gain benefits or financial rewards for relatives and close enterprises. President Xi made it clear that reasonable requests from enterprises should be fulfilled (Xi, 2018). Therefore, cronyism exists in China; however, it is important to 
distinguish "responsible cronyism" from "corrupt cronyism" (Andrews et al., 2019). In some industries, the use of cronyism is more common and almost expected, leaving some entrepreneurs to incorporate this to "play the game," but all of this happens within the "rules of the game" (Horak et al., 2018).

In this research, we focus on three example cases of how entrepreneurs have used cronyism. This paper focuses on motivations and behavioral patterns of cronyism to acquire resources, its impact, and the contingency mechanisms. The industry setting for this paper is China's property development or real estate industry, "a process that involves changing or intensifying the use of land to provide buildings for occupation" (Cadman \& Topping, 1995). We chose this industry for three reasons. First, China's real estate industry combines unique institutional and economic characteristics: China's political and legal environment and culture are different from most economies in the West, and the Chinese Government continues to strongly influence the industry through land releases and development rights grants (Wang \& Wang, 2012). Second, this industry has increasingly contributed to China's gross domestic product (GDP) since the early-2000s (e.g., 19.6\% to China's GDP in 2013 [Xu et al., 2016]). Third, property development is increasingly complex because of its multiple stages: originating an idea; refining it; testing its feasibility; negotiating a contract to ensure formal commitment; site construction; completion; formal opening; and property, asset, and portfolio management (Cadman \& Topping, 1995; Wilkinson et al., 2008).

The lack of attention in the existing literature on the process of cronyism was the catalyst for the concept in this paper. For example, recent research by Soleimanof (2016: 127) calls for "more research on cronyism to understand and identify its antecedents, consequences, and the mechanisms through which it is reinforced." This research is useful for both local entrepreneurs and foreign managers in multinational enterprises (MNEs). This research assists managers and entrepreneurs in obtaining insider status and critical resources. Next, we discuss the concept of cronyism, its motivations, and its impacts. We then focus on the context of the research and explain how this setting nurtures these networks and how entrepreneurs have to negotiate this environment to be successful.

\section{Literature review}

The word cronyism derives from the Greek “khro'nios” (Turhan, 2014), referring to a long-standing friend or companion (Stevenson, 2010; Collins English Dictionary and Thesaurus, 2000). During the 1840s, cronyism was used to describe the ability and eagerness to establish friendships (Turhan, 2014). The concepts of cronyism, favoritism, and nepotism relate closely to preferential treatment. Depending on the context, researchers use different terminologies to describe the phenomenon of cronyism, including nepotism, favoritism, and patronage (Turan, 2015; Turhan, 2014). Research into cronyism within politics, for example, applies it to when politicians prefer close or long-standing friends (Arasli \& Tumer, 2008).

In China, the relationship between guanxi and cronyism is related to channel and process. Figure 1 illustrates this process. Guanxi is a channel and foundation of cronyism. Therefore, guanxi itself is not cronyism, but the result of long-term engaging in guanxi may be cronyism (Leung et al., 2008). Guanxi may lead to cronyism, but 


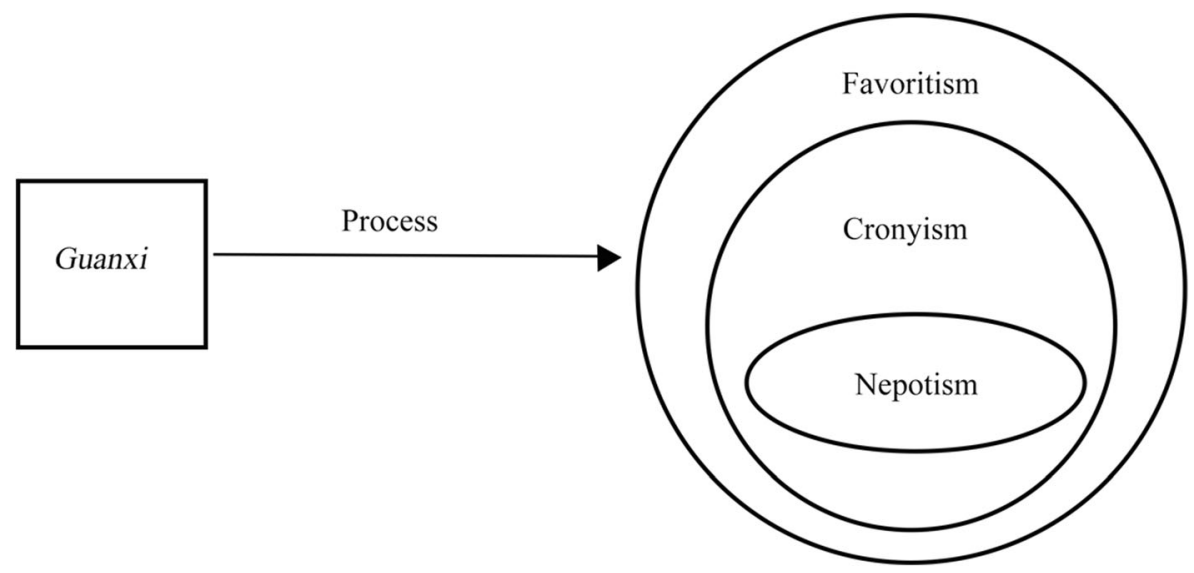

Fig. 1 Relationships among guanxi, favoritism, cronyism, and nepotism

cronyism is the act of favoritism itself (Khatri et al., 2006). Leung and his colleagues propose a guanxi-insider approach to show how a "new friend" obtain cronyism as a result through two guanxi adaption mechanism: renqing and mianzi (Leung et al., 2008).

\section{Cronyism, context, and culture}

The concept of cronyism can be understood through its local deployment, identity, and norms (Risjord, 2014; Root, 2000). Cronyism is not unique to emerging economies but is observed in all cultures with rather different manifestations (Cingoz \& Akilli, 2015; Hong, 2011; Khatri \& Tsang, 2003). In China, cronyism is deployed locally. This is largely related to the transitioning nature of China's economy. Transitioning economies are characterized by underdeveloped policies and legal structures to govern and guide business in a market-oriented economy (Hoskisson et al., 2000; Li \& Zhang, 2007; Naughton, 1999). For example, enterprises may be required to operate in a market where there is no contractual law, weak property rights, and underdeveloped capital markets (Kwock et al., 2013). In response to filling these voids, guanxi and informal networks substitute and support businesses instead of formal institutions (Xin \& Pearce, 1996). Therefore, in China, cronyism is considered culturally proper and ethical (Hooker, 2009).

Cronyism is taken up by individuals as part of their social identity. According to social identity theory, in-group favoritism occurs for group members to mentally enhance the favorable qualities of the relevant in-group to which they see themselves belonging (Greene, 2004). Cultural norms prescribe different treatments based on the practice of cronyism. Reciprocity norms and loyalty to members' interest in bonding networks tend to exclude outsiders (Tonoyan et al., 2010).

Some researchers argue that cronyism is similar to guanxi in Chinese culture and blat in Russian culture, although cronyism can generally involve both these culturebased concepts (Begley et al., 2010). Therefore, the specific properties of informal networking in different national contexts should be scrutinized (Lin \& $\mathrm{Si}, 2010$ ). 


\section{Distinguishing cronyism from related concepts}

In the Chinese context, cronyism differs from guanxi, favoritism, and nepotism in terms of selectivity and time (Zhai, 2011). Guanxi is different from social networking practices that typify Western research in terms of two dimensions: time and space. Figure 2 illustrates the characteristics of guanxi. It shows guanxi is firstly long-term and low-selective, where low-selectivity refers to guanxi being open only to people with similar guanxi characteristics but closed to people involved only in a normal business, trade, and communications (Zhai, 2011: p. 300). Guanxi being part of the culture is a higher-order concept, and it describes reciprocal "personal relationship networks of informal social bonds... [whereby] individuals carry expectations and obligations to facilitate [the] exchange of favors" (Leung et al., 2008: p. 23). While cronyism is a networking approach, strategically developed by engaging in networking activities, guanxi (Begley et al., 2010) is used as a channel to obtain favor (Khatri et al., 2006), and it is not instrumental in building long-term value relationships in all cases. The success of networks that rely on guanxi also depends on contingency and exchange hazards, uncertainty, and lack of clarity (Chu et al., 2019).

Conversely, cronyism is a networking approach, strategically developed by engaging in networking activities and guanxi (Begley et al., 2010), for which guanxi provides the channel to obtain favor (Khatri et al., 2006). Favoritism may be in-group or outgroup; for instance, it provides special privilege to friends and colleagues in the areas of employment, career, and personnel decisions (Arasli \& Tumer, 2008). It can be longterm or short-term with many or few alternatives. Nepotism is a specific type of cronyism that applies to family members (Khatri et al., 2006). Nepotism appears in two primary forms: entitlement and reciprocity (Jaskiewicz et al., 2013). These types differentiate to accommodate the family conditions of interdependence, previous interactions, and cultural norms, rather than pure family ties (Jaskiewicz et al., 2013). Cronyism applies to favoring members within the same group, such as family members or people from the same workgroup, over long-term interactions (Yin-Wah, 2007). Based on Zhai's (2011) model, cronyism is long-term and has few alternatives.

China has a long history of cronyism. Chinese people commit to each other on a long-term basis through the hidden norm of reciprocity involving equity and exchanging favors (Luo \& Chen, 1997). For instance, Li's (2017) research into China's military

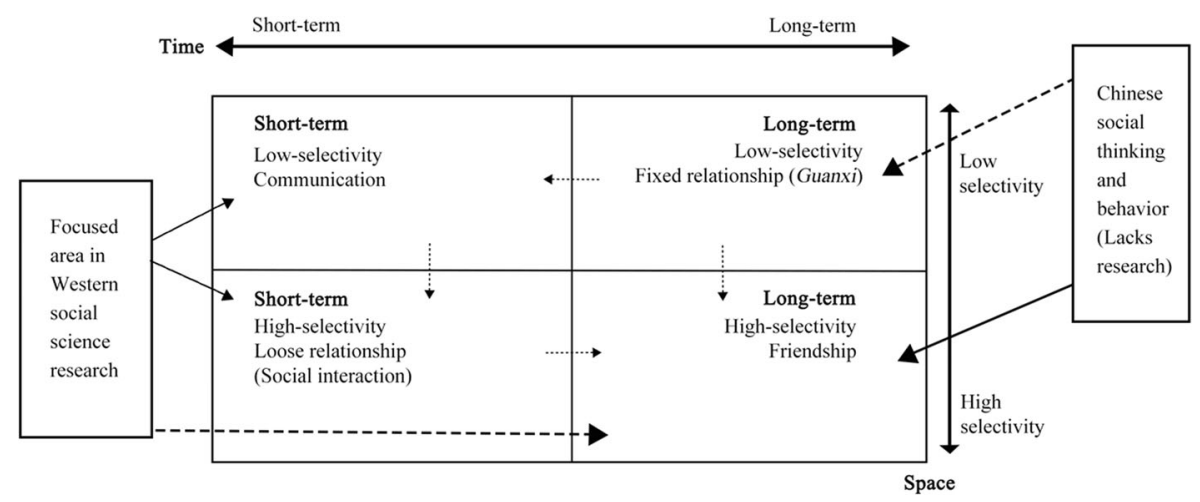

Fig. 2 Dimensions of guanxi and characteristics (Zhai, 2011: pp. 297-298) 
notes that the Chinese decision-making process remains heavily influenced by "personalism" or personalistic power (renzhi). Renzhi produces opportunities for upperlevel leaders, including government officials, to build personalistic networks as a means of increasing their leverage. Cronyism seems to be inevitable as leaders tend to prefer their loyalists for prominent positions. The clear difference between cronyism and corruption is whether the action hurts the benefits of a third party (Andrews et al., 2019; Khatri et al., 2006).

\section{Motivations of cronyism}

The two types of cronyism - instrumental and relational - have different motivations (Khatri et al., 2006). Instrumental cronyism is utilitarian and self-interest-based; it is usually time-restricted and mainly based on an exchange of favor including preferential treatment to associates without considering their qualifications - this imbalance can lead to negative impacts at both country and enterprise levels (Leung \& Barnes, 2020).

Relational cronyism is motivated by relationships, affection, and loyalty (Khatri et al., 2006). It is mainly based on an obligation or a duty to assist those in the same network group. This reciprocity rationale is deeply embedded in Chinese culture (Redding, 2002; Westwood et al., 2004). Leung and Barnes (2020) note the relational linkages can help generate ethical cronyism to leverage performance advantages.

\section{Impacts of cronyism}

Instrumental cronyism without considering associates' qualifications lead to negative impacts. Existing literature focuses on the negative impacts at different levels (Enderwick, 2005; Khatri et al., 2003, 2006; Pearce, 2015). Weber (2001) argues cronyism is detrimental to economic growth since it restricts economic freedom and income equality (Walder, 2002) and leads to entry barriers (Smith \& Sutter, 2012). Cronyism is also detrimental to firms because it can lead to poor management, waste, lower productivity, and poor performance (Alon, 2003; Su \& Lee, 2013).

Relational cronyism is more likely to produce positive impacts. In this instance, cronyism can assist firms because "all parties know each other and actors with longterm, close, and overlapping personal ties can sanction each other and spread information more easily" (Kang, 2003: 442). Cronyism can also accelerate trust-building and mutual understanding that eventually lead to more effective relationships (El-Said \& Harrigan, 2009; Hsu \& Saxenian, 2000). Although Chinese people do not often trust those outside their social network (Atuahene-Gima \& Li, 2002), they can improve enterprise performance using reciprocal nepotism, where they favor social exchange relationships among family members (Jaskiewicz et al., 2013).

Therefore, the key issue is the benefit to third parties: cronyism is not a problem when it does not reduce a third party's benefits (Krug \& Hendrischke, 2003) but is harmful when public or private officers misuse their positions to distribute resources to friends or relatives without considering other applicants who are better qualified (Loewe et al., 2007). It is also a problem when a dependent is exploited by the misuse of power (Krug \& Hendrischke, 2003). Regarding public policies and rules, Salter (2014: 10) argues that whether cronyism leads to corruption depends on factors such as "unique access to public decision-makers by beneficiaries, their overwhelming 
financial resources in lobbying public officials and financing their campaigns, and other means of crowding out opponents' views... [and] implicit quid pro quos." The legitimate use of close relationships that have a long history and that are embedded in some cultures should be differentiated from corrupt cronyism. Cronyism behaviors only approach a form of corruption when private entities benefit from abusing public authority (Salter, 2014).

\section{Entrepreneurial resource acquisition and developmental stages}

Entrepreneurs face considerable challenges in acquiring resources (Brush et al., 2001) during the start-up stages of venture creation. When enterprises are regarded as new and uncertain, resource owners are concerned with the viability of new ventures (Zhang, 2010). The resources needed include financial resources (Khan et al., 2019), specialized human resources, and market access (Zhang, 2010). Existing theories and empirical evidence confirm the benefits of using social networks in entrepreneurial resource acquisition (Greve \& Salaff, 2003; Miller, Besser \& Malshe, 2007).

This is especially the case in an emerging market characterized by institutional voids and a lack of institutions that support market transactions (Gao et al., 2017; Khanna \& Palepu, 2010). To survive, emerging market firms must cope with unpredictable circumstances, including political instability, violence, and macroeconomic fluctuations (Khanna \& Rivkin, 2001). To overcome these institutional voids, network research into entrepreneurial resource acquisition highlights the importance of direct ties between entrepreneurs and resource owners (Xin \& Pearce, 1996) and using catalyzing strategies (Hallen \& Eisenhardt, 2012).

In China, research highlights that Chinese private enterprises face barriers to obtain critical resources, such as formal finance (see Poncet et al., 2010; Tsai, 2002; Wu et al., 2008). Research shows that, while the Chinese Government may favor state-owned enterprises (SOEs), it also discriminates against private enterprises. Despite the government having gradually encouraged small and medium-sized enterprises to develop, it remains difficult for them to access external funding from banks under such discrimination (Cousin, 2011; Poncet et al., 2010; Wu et al., 2008).

Cronyism is used to acquire resources throughout the different business development stages, to gather information, build influence, and create solidarity (Adler \& Kwon, 2002; Sandefur \& Laumann, 1998). This staged framework provides a tool for comprehensive analysis, as it covers the social and economic influence of social networks (Zhang, 2010). Cronyism may show generally and simply how entrepreneurs should strategize to gain entrepreneurial resources. However, we need more research to ascertain the process of how these enterprises use cronyism to obtain access to crucial resources (Salter, 2014; Smith \& Sutter, 2012). Our research adds to a better understanding of how cronyism is used as a strategy to facilitate access to resources and to navigate the specific cultural context demands.

\section{Methodology}

This study uses a multiple-case-study method (Eisenhardt, 1989; Yin, 2009). Compared to single case studies, multiple-case-study research has the advantage of building 
more generalizable, robust, and parsimonious theory (Eisenhardt \& Graebner, 2007). A multiple-case-study method contributes to research in two ways. First, it allows systematic comparison to reveal similarities and differences among cases and how they affect findings (Ridder, 2017). Second, the multiple-case-study method provides a holistic approach (Gummesson, 2007), but with more in-depth information on how entrepreneurs develop, how cronyism is used, and the point at which it impacts enterprises' capacities to obtain crucial information and resources.

Given the theory-building nature of this research, we used theoretical sampling to select focal enterprises (Eisenhardt, 1989). In contrast to random sampling, focusing on obtaining accurate statistical evidence, theoretical sampling is purposefully non-random (Eisenhardt \& Graebner, 2007). We chose cases to explain the "how" question of the research. The cases also allowed us to include the context, which played an important role in understanding the phenomenon of interest (Eisenhardt, 1989; Ridder, 2017) and provided a real-life snapshot of the complexities and dynamics involved in the context (Yin, 2006). Following the ideal of "no theory first" (Ridder, 2017: 286), theoretical sampling is deemed to be appropriate for extending constructs and identifying relationships for the phenomenon under investigation (Eisenhardt \& Graebner, 2007).

This research focuses on private enterprises in China's property development industry since this industry is known for its resource constraints, difficult market environment, the lack of regulatory licenses and information, and limited access to land, finance, and specific knowledge (Zhu et al., 2012). We focused only on private enterprises for two reasons. First, this industry has become an important pillar in China's economic development and acts as a barometer for China's prosperity and economic growth (Leung, 2010). Second, private enterprises provide a more obvious setting to study the impacts of cronyism as it relates to the resources that are central to growth; that is, land access and finance. Because private enterprises, unlike most SOEs, are not privileged with crucial information and crucial resources, they need to find ways to cope with these barriers.

Our sample consists of three private property development enterprises located in the same industry and the same regional city. It is a second-tier city at the prefecture-level, located in the northern part of China. Selecting one city involved a deliberate attempt to make the analysis more meaningful because local government significantly influences the establishment and development of private property development enterprises. Since local governments are flexible in implementing policy, having three cases in the same city presented a setting in which the political environment mirrors the economic environment, thus enabling the cases to be more meaningfully compared. The city has a population of 4.69 million with a GDP per capita of CNY 94,827 (USD 14,593). Although prefecture-level cities may not compare with the biggest cities, such as Beijing or Shanghai, they nonetheless comprise $88 \%$ of China's prefectures. An indepth study of enterprises in one prefecture-level city will thus shed light on other enterprises in similar settings.

All three enterprises were established at a similar time (i.e., between 1993 and 1997). Our interview questions apply to the period from when the enterprises were established to 2012 when we conducted the in-depth interviews. This period allowed us to investigate and compare the impacts of cronyism at the firms' start-up and growth stages. From 2012 to date, we continually followed up with these firms to ensure the information was up to date. 
The initial case selection started with five enterprises through our personal networks. However, after preliminary interviews with key informants of the enterprises, we chose three enterprises because they differed in size, number of employees, the scope of guanxi brokerage, and professional experience. Table 1 displays information about the sampled enterprises, their entrepreneurs, and projects.

\section{Data collection}

We used several data sources, including interviews, follow-up phone calls, and archives such as company websites, internal documents, and newspaper articles. The triangulation of data sources enhances the accuracy of information and reliability of emergent theory and case findings (Anand et al., 2007; Hallen \& Eisenhardt, 2012).

The data collection started with informal preliminary interviews. Because one of our personal contacts was familiar with all three case enterprises and was also a research participant in two of them, we contacted him first for an informal personal chat. Following that, we conducted preliminary informal interviews in January 2010 to gradually build trust with the potential informants.

Table 1 Description of cases

\begin{tabular}{|c|c|c|c|c|c|}
\hline $\begin{array}{l}\text { Enterprise } \\
\text { name }\end{array}$ & $\begin{array}{l}\text { Founding } \\
\text { year }\end{array}$ & $\begin{array}{l}\text { Number } \\
\text { of projects } \\
\text { conducted }\end{array}$ & $\begin{array}{l}\text { Position/ } \\
\text { Number of } \\
\text { informants }\end{array}$ & $\begin{array}{l}\text { Number } \\
\text { of interviews }\end{array}$ & $\begin{array}{l}\text { Entrepreneurs' } \\
\text { professional } \\
\text { background }\end{array}$ \\
\hline Yang's Property & 1997 & 6 & $\begin{array}{l}\text { GM: } 1 \\
\text { Vice GM: } 1 \\
\text { Former company accountant: } 1 \\
\text { GM's brother: } 1 \\
\text { Head of Construction Committee: } \\
\quad 1 \\
\text { Head of Bureau of Planning: } 1 \\
\text { Former superior: } 1 \\
\text { GM of a client company: } 1 \\
\text { Former Secretary of the Party } \\
\quad \text { Committee: } 1\end{array}$ & 15 & $\begin{array}{l}\text { No previous experience } \\
\text { with the property } \\
\text { development } \\
\text { industry }\end{array}$ \\
\hline $\begin{array}{l}\text { Wisdom } \\
\text { Property }\end{array}$ & 1993 & 13 & $\begin{array}{l}\text { General Director: } 1 \\
\text { GM: } 1 \\
\text { Vice GM: } 1 \\
\text { External accountant: } 1 \\
\text { Administrative Officer of Local } \\
\text { City Housing Administration } \\
\text { Bureau: } 1 \\
\text { Director-General of Housing } \\
\text { Administration Bureau: } 1 \\
\text { Bank Manager of a state-owned } \\
\text { bank in Local City: } 1\end{array}$ & 10 & $\begin{array}{c}\text { Co-founders are } \\
\text { architectural } \\
\text { designers }\end{array}$ \\
\hline East Property & 1994 & 8 & $\begin{array}{l}\text { GM: } 1 \\
\text { Company lawyer: } 1 \\
\text { Close friend: } 1 \\
\text { Former superior/village mayor: } 1 \\
\text { Lawyer: } 1 \\
\text { Administrative Officer of Local } \\
\quad \text { City Housing Administration } \\
\quad \text { Bureau: } 1\end{array}$ & 10 & $\begin{array}{l}\text { No previous experience } \\
\text { with the property } \\
\text { development } \\
\text { industry }\end{array}$ \\
\hline
\end{tabular}


The primary data source comprised 35 in-depth interviews with participants who were closely involved in projects of the case enterprises. These involved double or triple interviews with some informants, such as the entrepreneurs and other informants who participated in their property development projects. Very little information about these three case enterprises was publicly available. Only one has its own website. No autobiographies of the entrepreneurs were available; the only and best way to obtain such information appeared to be talking to informants of the case enterprises. Data collection included two field trips. During the first field trip, 18 in-depth interviews were undertaken from June to July 2011, with 15 in-depth interviews being undertaken during the second field trip from February to March 2012. For reasons of anonymity, all the names of individuals, organizations, companies, and places have been assigned pseudonyms.

The data collected included general company information, information about the personal development of entrepreneurs, and land-access, regulatory, financial, and internal management barriers they had faced in every property development project, and how they overcame these barriers. While we used open-end questions in the interviews, follow-up questions evolved during informant discussions. For example, when informants addressed the way they overcome barriers, we focused on the cronyism practices involved. Nevertheless, the data remain relevant and important to this paper, as the focus is on the entrepreneurial process - in particular, how entrepreneurs used cronyism practices to obtain resources. The reflections and outcomes of their actions can be viewed as a "life story" (Creswell, 2007: 55) and the observations include the full breadth and depth of the process. The cases offer insight that is universal to any situation where entrepreneurs face this context, and the examples offer the opportunity to learn from their experiences. The data do not focus on how entrepreneurs perceive cronyism practices; rather, the data focus on how entrepreneurs have addressed barriers in each past property development project using cronyism practices; thus, these data will not change over time.

Following Glaser's (1978) recommendation, during the data collection, we kept the interview styles and sites flexible, followed up on recurring patterns, and asked participants to tell us more. For instance, for one entrepreneur who kept changing the interview time for business reasons, we managed to conduct it at a park where he usually does his morning exercise. There was less interruption there compared to the business office where he needed to respond to phone calls and other business matters; the entrepreneur was thus willing to share more information at the park.

We took several measures to address potential information biases. First, the interviewees comprise informants with different positions, but which closely related to the enterprises. These interviewees included internal management staff and external personnel such as government officials who were involved in the property development projects, and family members and close friends of the entrepreneurs who were also involved in the company's business transactions. Second, following Eisenhardt's (1989) case study method, we avoided speculation by focusing on factual, objective accounts of what informants did or observed others doing to increase accuracy. Third, we triangulated data among different sources to check our findings, to increase credence in the interpretation, and to show when an assertion might be common (Stake, 1995). 


\section{Data analysis}

Guided by Eisenhardt and Graebner's (2007) case study methods, we used within-case and cross-case analysis without a priori hypotheses. More specifically, this research used inductive analysis as suggested by Gioia et al. (2013). Gioia et al. (2013) exemplifies the analysis path from the quotes to the first-order concepts, the secondorder themes, and the aggregate dimensions. The first-order concepts were primarily applied to informants' experiences and voices (Corbin \& Strauss, 2014). The secondorder themes, reflecting emerging theoretical concepts that describe and explain the phenomena, were categorized by our research team. Detailed strategies used by enterprises are summarized in Table 3 in the Appendix.

During the open coding and second-order categorization, we relied mainly on field notes. We wrote individual case narratives using information collected in interviews and archives. Our triangulation of data used different data sources, such as information from company documents, websites, and newspapers. To fill any information gaps and confirm missing details, we undertook a second field trip (February to March 2012) and phone calls were made as necessary (post-March 2012). The case narrative for each enterprise was 44 to 64 pages, including words, timelines, and tables. The data structure for the case narratives comprises a company profile, entrepreneurs' personal development before establishing their own companies, barriers met in each project, and how these barriers were addressed.

To generate second-order themes, we performed within-case analysis using these individual case narratives, using each enterprise as the unit of analysis. First, we classified the information according to each property development project; within each case, we investigated their strategies of using cronyism to obtain regulatory information and crucial resources, including land and finance. We then compared them to using cronyism to address different barriers at different stages of firm development.

Relying on replication of logic, we conducted cross-case analysis across the three sampled enterprises to search for consistent patterns (Yin, 2009). We analyzed how individual enterprises addressed different barriers across their property development projects. We also analyzed how the same barrier was overcome across the three case enterprises. We used tables to compare the three enterprises with different levels of cronyism when facing barriers to investigate the similarities and differences. For example, all three enterprises showed the positive impacts of cronyism in assisting them to obtain crucial resources in the early stage of business development, but the various levels of cronyism used in later stages produced different firm performances.

During data analysis, we compared case data, theory, and existing literature (Glaser $\&$ Strauss, 1967) to refine construct definitions, abstraction levels, and theoretical relationships. We kept all iterations until theoretical saturation was reached, a close match between theory and data (Glaser \& Strauss, 1967). Theoretical saturation was reached after two rounds of interviews when no new themes emerged and no new dimensions or subthemes could be identified. The third round of interviews was conducted to add to the richness of the quotes (Blaikie, 2000). We conducted member-checking by contacting the interviewees to ensure our findings involved correct interpretations. We used member checking and also contacted the participants after the coding or where some of the themes seemed to fit under more than one order of discussion to clarify what they meant and to provide more background on their 
thinking. We ensured that the information was true, applicable, consistent, and neutral (Krefting, 1991). This ensured that the themes were interpreted correctly for quality control to ensure trustworthiness and rigor (Harper \& Cole, 2012). We now discuss the findings.

\section{Results}

Cronyism is built on the trust of the people involved and in the process. Table 2 summarizes the entrepreneurial characteristics of the entrepreneurs, including personal traits, personal trust in entrepreneurs, entrepreneurs' previous work experience, the scope of their networking, and community involvement. All entrepreneurs were considered trustworthy by related parties; that is, clients, superiors, and close friends and family members. All of them had work and management experience in government departments or large SOEs before establishing their enterprises and had engaged the community in their business operations. According to interviewees, successful cronyism requires persistence, innovation, and flexibility.

\section{The process of cronyism}

\section{Cronyism strategies used}

This study investigates Chinese entrepreneurs in the property development industry, finding that they employed cronyism practices when managing their start-up ventures and during the later stages. According to the case analysis, cronyism practices comprise three main types: cronyism within the family relationship, cronyism within the relationship between government officials and entrepreneurs, and cronyism with previous clients. The process of cronyism usually involves an Initiator (individuals who initiate the cronyism practice), a Resource Owner (the individuals who have access to or control of crucial resources), and a Legitimator (individuals or companies that legitimate the cronyism practice) or an Intermediary (network brokers).

All three case enterprises have received preferential treatment from close family members, government officials, superiors, or previous clients. Despite the similarities across the three firms, we found that the cronyism networks were used in different ways and to achieve different outcomes. For example, when referring to land as an essential resource needed to begin the venture, all entrepreneurs had to negotiate government power and the controlling officials.

\section{Motivations for cronyism}

The underlying rationale is that entrepreneurs who use cronyism practices share some common motivations and behavioral patterns; however, there are some heterogenous motivations as well. We observed that the motivations for engaging in cronyism are different for entrepreneurs and resource owners. In Yang's case, Yang's elder brother, Guang Yang, as the resource owner, felt it was his obligation to look after his younger brother, recalling: 


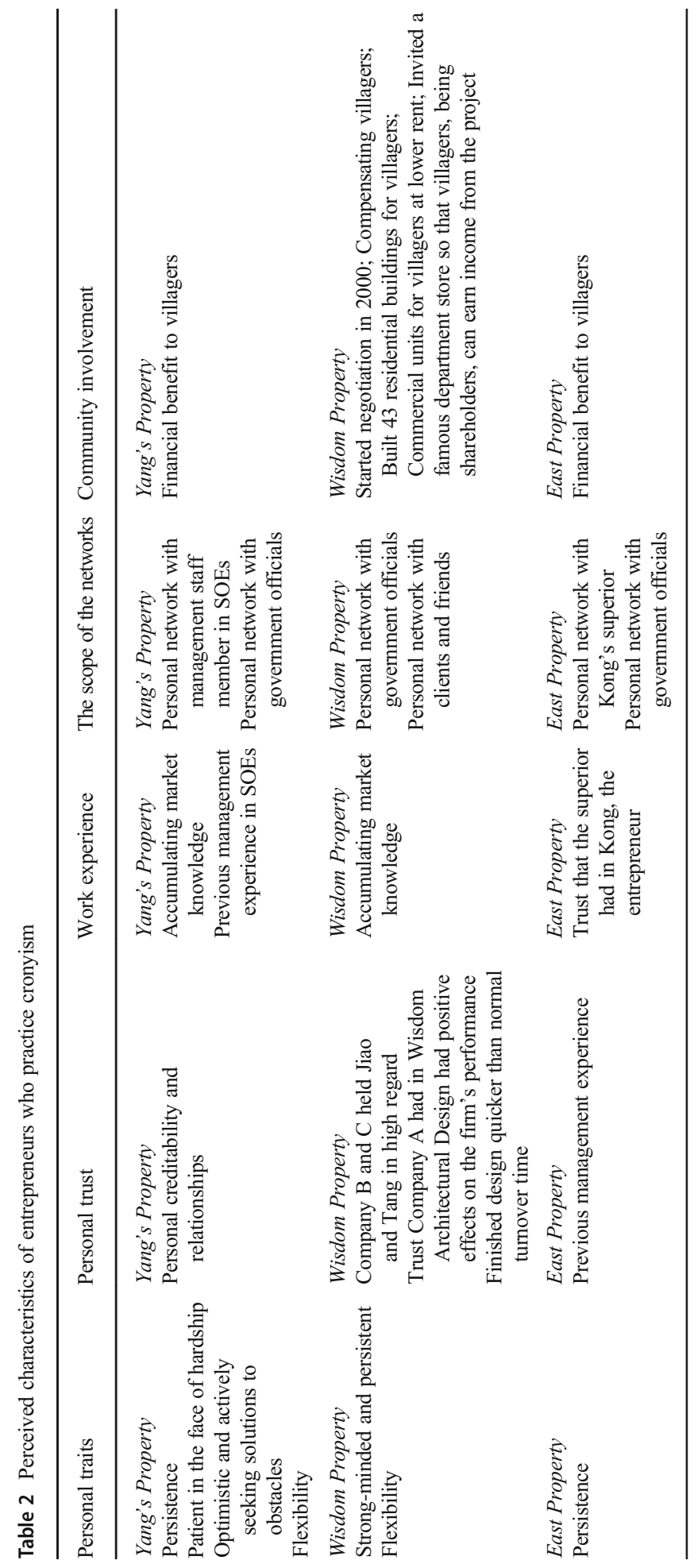




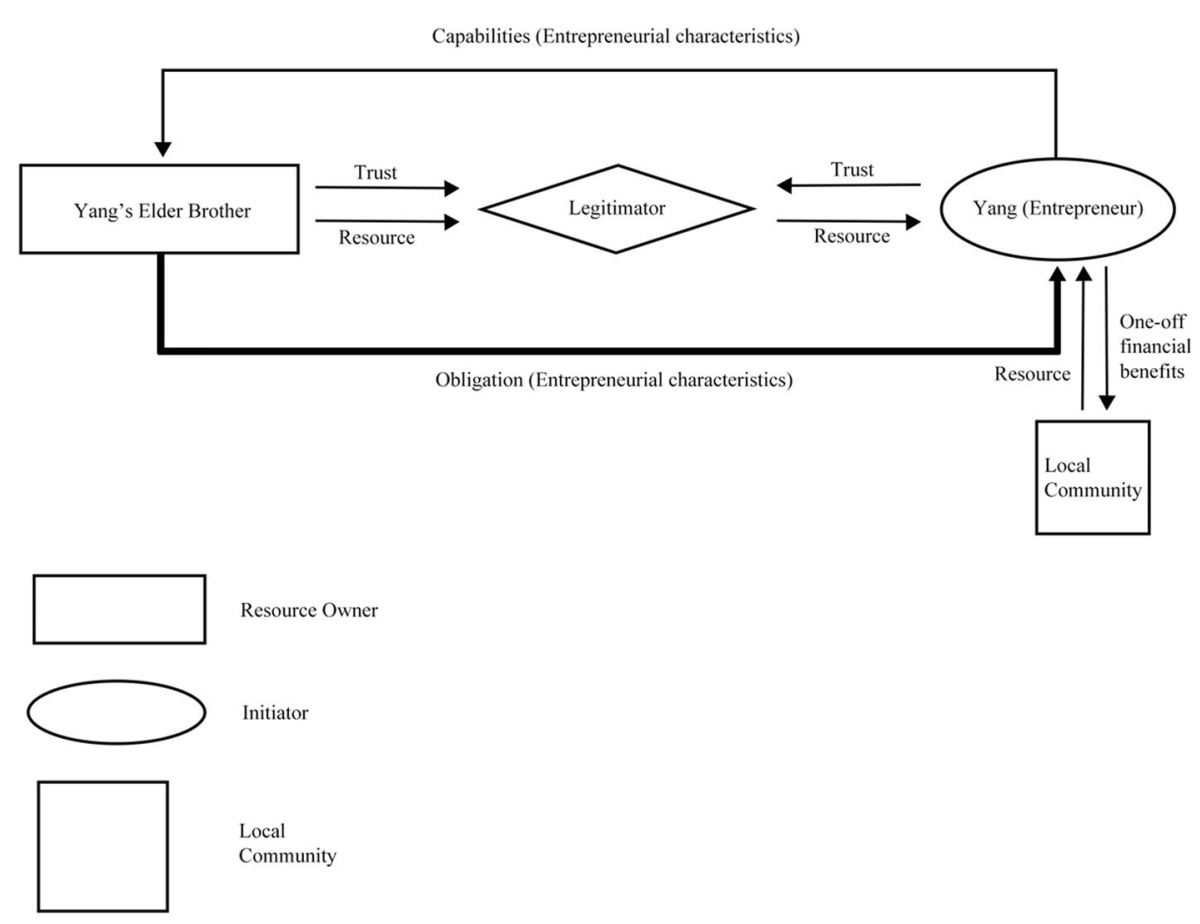

Fig. 3 The process of cronyism: Yang's Property

In 1977, I took eight-year-old Yang to attend primary school in Baojiang District, the central district of [Local City] ... I was more like Yang's father than an elder brother. I took care of Yang's life and studies. And this continued in his later life and career pursuit. (Interview, Guang Yang, 29/06/2011)

The notion of family obligation is embedded in Chinese culture with obligation being an entrepreneurial characteristic (as seen in Fig. 3). However, the entrepreneurs' motivation was also driven by economic factors since they needed the land to start the property development.

In the second case, the motivation for resource owners to engage in cronyism was the recognition of the entrepreneurs' track record and reputation (as seen in Fig. 4). The two entrepreneurs were architectural designers who had built trust with their clients through their professionalism. For example, when the entrepreneurs left their previous SOE, they had not gained formal business qualifications to design reports as a company, while their previous client, Company A, still insisted on having them as the designers. This illustrates that it is not only purely credentials in the form of formal qualifications that will build networks in this context, but also how individuals conduct themselves and how others see them. One of the entrepreneurs, Jiao, recalled:

Company A had our design and took it to another qualified design company and used their qualified company name on the final design. This might have been a risk for Company A, as we did not have a company to produce the design, which meant that Company A had no guarantee that their design would be up to 
standard. However, Company A still had us as the designers, and it indicated the high regard in which Company A held our reputation report. (Interview, Jiao, 11/ 07/2011)

In the third case, policy change was the main factor facilitating East Property to obtain land (see Fig. 5). The company was privatized, having originally been a village-owned property development company. The motivation for the resource owner was to find an appropriate staff member to fill the position in a very limited time. Kong, the entrepreneur, had run the village-owned property development company for 11 years and was familiar with the firm. Therefore, he was the only appropriate person to take over the company, as Han, the Village Mayor, and resource owner, recalled:

In 2003, a government policy triggered the privatization of Childer Village Property. In 2003, the Local City Government advocated that collectively owned enterprises should become privatized. (Interview, Han, 06/03/2012)

However, in the beginning, the company was not privatized as a favor to Kong, as he needed to bear a debt from the village as a condition of the privatization. In fact, Kong stated that the agreement with Childer Village to privatize the village-owned property development company was "extremely unfair" to him (Interview, Kong, 14/07/2011). Kong recalled:

An important reason to privatize Childer Village Property was to resolve the serious loss in Childer Village's other collective firms, such as the electric motor firm and maintenance firm. As a condition attached to the privatization of Childer Village Property, Han asked me to bear a debt of RMB 500,000 [US\$80,093]. (Interview, Kong, 14/07/2011)

\section{The usefulness of a third party}

We observed the involvement of a third party when using cronyism to acquire critical resources. In Yang's case, his elder brother appointed a nominal developer to one of his projects. In Guang Yang's view, the reasons for seeking a nominal developer were twofold:

The first reason was, having a nominal developer could make my relationship with Yang less obvious to the public. Many staff members were aware Yang was my brother, so it would be too obviously a case of nepotism if TIT cooperated with Yang directly. The second reason for having a nominal developer was that it could resolve the issue of Yang's shortage of funds. (Interview, Guang Yang, 29/ 06/2011)

The usage of a third party, in this case, is consistent with findings in the existing literature (Obstfeld et al., 2014; Su \& Littlefield, 2001). In Fig. 5, we name this third party as "legitimator" to distinguish them from an intermediary or a network broker. 


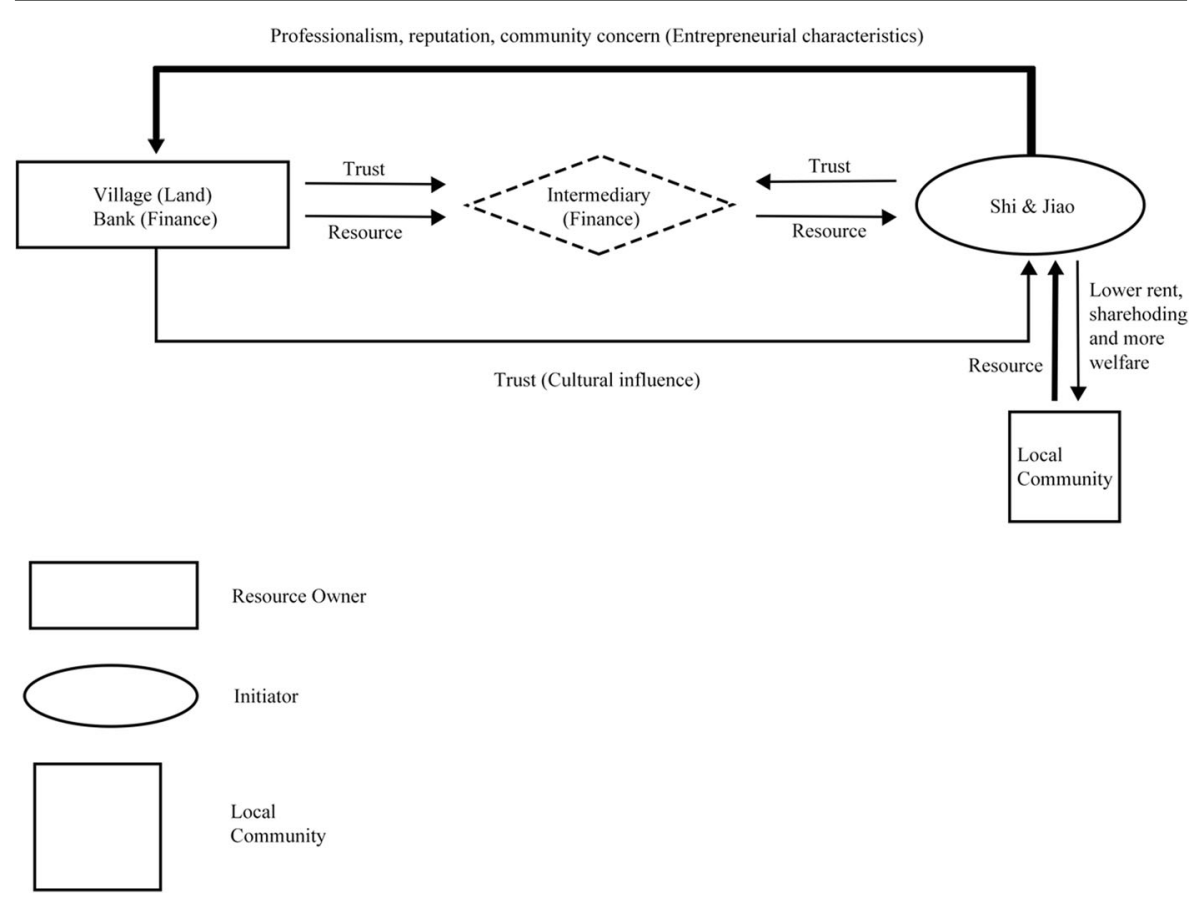

Fig. 4 The process of cronyism: Wisdom Property
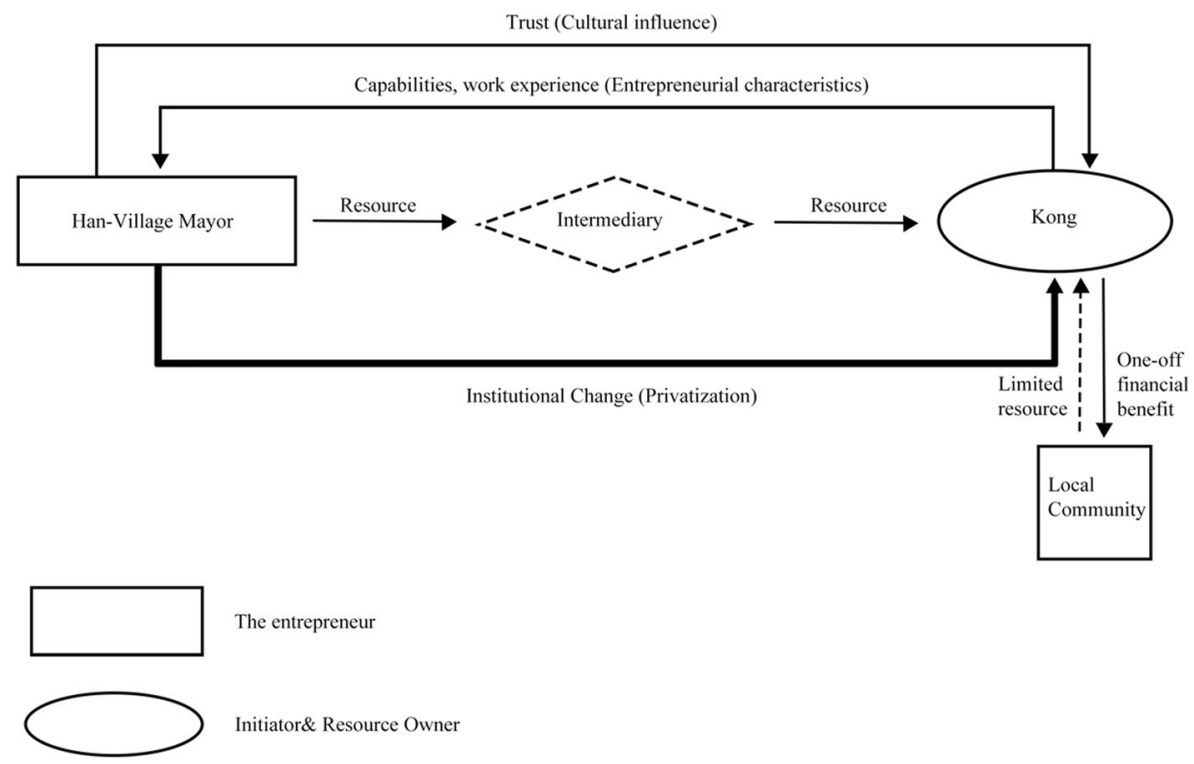

The entrepreneur

Initiator\& Resource Owner

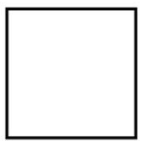

Local

Community

Fig. 5 The process of cronyism: East Property

\section{照 Springer}


Intermediaries relate closely with at least one party and connect both parties by introducing them as a friend or collaborator (Su \& Littlefield, 2001: 207). A network broker is related to the activity in which third parties facilitate the interactions of other actors (Obstfeld et al., 2014). However, legitimators differ in how they operate in that both parties know each other very well. Legitimators are people or organizations that meet the formal requirements of the resource owners and thus legitimize the transactions but do not participate in the real company management. The reason for having a legitimator is to obscure the close guanxi between the resource owner and the entrepreneur even when the entrepreneur's company is fully qualified.

\section{The impacts of cronyism}

\section{The specific impact of cronyism}

The similar and distinguishing motivations also apply to the impacts of the three types of cronyism. In general, the three types of cronyism were found to benefit entrepreneurs in the aspects of obtaining critical resources: land and finance. We found two contingency working mechanisms for the practice of cronyism. The first is that the entrepreneurial characteristics matter to their cronyism and its impacts. Several factors were found to be salient - the entrepreneurs were found to be persistent, innovative, and flexible. The second contingency working mechanism is that the stage of enterprise matters. Hence, we found a staged model for cronyism and its impact, reflected in the fact that during the earlier stages, cronyism matters the most, and when the enterprise progresses to a later stage, entrepreneurs who pay more attention to community involvement and the build-up of managerial capabilities have more positive impacts on resource acquisition.

\section{The increasing importance of community involvement}

All three companies engaged with local communities but at different levels. For instance, Yang's Property and East Property primarily provided financial incentives to villagers to acquire land converted from agricultural land. However, Wisdom Property took the community involvement further by providing more benefits to the villagers (as seen in Fig. 4). Tang recalled:

In addition to the 43 residential buildings constructed for the villagers, we also provided means of production to villagers in Gold Village in the following two ways. Firstly, we designed commercial units in the Gold Garden project, but instead of selling or renting to the public, Wisdom Property reserved all these units for villagers in Gold Village at a very low rent, RMB 600/month (US\$94/ month). This meant that villagers had opportunities to open stores and to earn their living as grocers. Secondly, Wisdom Property built a building suitable for retail premises for Gold Village. Gold Village then invited a famous department store into this building. In this department store project, villagers collectively owned 70 percent of the profit and the village committee owned the remaining 30 percent. (Interview, Tang, 27/02/2012; People's Daily Online, 12/05/2005) 
Wisdom's strategy was more consistent with traditional Chinese thinking: "Give a man a fish and you feed him for a day. Teach him how to fish and you feed him for a lifetime". Also, this is a more sustainable and future-thinking way of engaging local communities.

We also found that cronyism and guanxi change in a dynamic way. For example, rather than being a close tie, such as a family or kinship tie, guanxi can be formed in later life stages. For cronyism, it is also possible that the previous relationship is broken, and a new relationship is formed through community involvement.

\section{Networking diversity}

Comparing the three cases, we found the size of the entrepreneurs' networks across the three case enterprises varied by density (i.e., by closeness and familiarity) and by how many direct ties they have (i.e., to those directly involved in the process). Yang's Property mostly relied on the entrepreneur's personal network with his elder brother, who was the General Manager of a large SOE; Kong from East Property used mainly guanxi with his superior, who was the village's Mayor. However, Wisdom Property dominated the networks. It kept close guanxi with Gold Village, where they successfully developed five projects on their land. Meanwhile, they have guanxi with other clients and government officials.

\section{Research proposition}

To understand how cronyism is practiced, it is necessary to understand the underlying motivators of the behavior, as well as the nature of the relationships. The case evidence emphasizes the importance of long-term connections. Cronyism is based on trust (Khatri et al., 2003; Leung \& Barnes, 2020). Actions rely on trustworthiness. Trustworthiness is based on the personal behaviors and characteristics of the entrepreneurs rather than the organizations they manage. This is consistent with Li's (2008) view that Chinese firms involve a relationship-specific personalized trust that relates to relationship-specific, rational, moral, and affective goodwill. For instance, because Yang's elder brother was motivated by the obligation to his younger brother, in some cases, the elder brother discovers, explores, and exploits the opportunity rather than Yang. His elder brother looked for opportunities in which he believed his younger brother to be competent. This may be rooted in the paternalism that plays an important part in China's changing social context (Huang et al., 2005; Redding, 2008).

The entrepreneurs share similar personality traits with the resource owners or, through long-term interaction, the entrepreneurs show their own personal traits, such as being benevolent and self-disciplined. This accords with the literature on being a "moral person" and "moral manager" to conduct ethical leadership (Wang et al., 2017). At the same time, the entrepreneurs have proven their own capabilities to the resource owners through their previous work experience. In some cases, the resource owners have interacted with the entrepreneurs in previous business transactions for another SOE where the entrepreneurs used to work. As such, we propose: 
Proposition 1 A shared cultural context and behavior pattern have a positive influence on resource acquisition through cronyism.

The stage the enterprise matters in terms of the cronyism practices employed. Figure 6 presents how the contingency working mechanism of cronyism works in the start-up and growth stages in China. We find that cronyism works in a circular motion and is important in both developmental stages of the firm. The difference between the two stages is the use of managerial capabilities and community involvement.

Relationships and the influence of these relationships on the kind of resources that the start-up can access and the speed at which they can access them are widely noted in the literature (Edelman et al., 2016; Kellermanns et al., 2016). Marion, Eddleston, Friar, and Deeds (Marion et al., 2015: 167) describe how entrepreneurs manage these relationships, especially in the start-up phase, as being "socioemotional bonds with their alliance partners." The strength of the connections will influence the strategic decision of how involved the entrepreneur will be in the relationship and to what extent the involvement will be (Peng \& Zhou, 2005). We found that Peng and Zhou's (2005) suggestion that emerging economies could potentially face power struggles in strongtie networks could influence how the network develops. For instance, we found that, in the start-up stage, the case enterprises had strong guanxi with the resource owners: the elder brother, government department officials, and the local village mayor (who was crucial for acquiring village-owned land). This guanxi is usually the personal guanxi between the entrepreneur and those in charge.

Cronyism is described as a social norm, and reciprocity is expected (Khatri et al., 2016). The level of reciprocity and the extent of the involvement seems to be open for interpretation according to the situation. Entrepreneurs and resource owners adapted their cronyism practices according to the (1) enterprise-government relationship and (2) the power distance in the relationship in terms of the level of superiority in the work or family relationship.

Therefore, we suggest that, during the start-up stage, cronyism is more likely to result in resource acquisition (see Figs. 3 to 5) and propose that:

Proposition 2 During the start-up stage, cronyism involving family relationships and cronyism within the relationship between government officials and entrepreneurs are the most effective in assisting entrepreneurs in obtaining critical resources.

When enterprises move to the growth stage, all the factors in the start-up stage remain. However, we also found the usefulness of cronyism, as detailed in the start-up stage, is U-shaped and diminishes or even stops when enterprises enter later developmental stages. During the start-up stage, cronyism can positively impact access to land and finance. The requirements for managerial capabilities and the entrepreneur's capability to make business decisions and lead their subordinates within the company during this time are relatively low. Therefore, when enterprises successfully obtain crucial resources - in this case, land and finance - enterprises can easily navigate the start-up stage. We found that the three enterprises successfully survived in the start-up stage by either relying on cronyism, such as with Yang's Property, or by adopting a more market-oriented approach, as with Wisdom Property. However, to survive the growth 

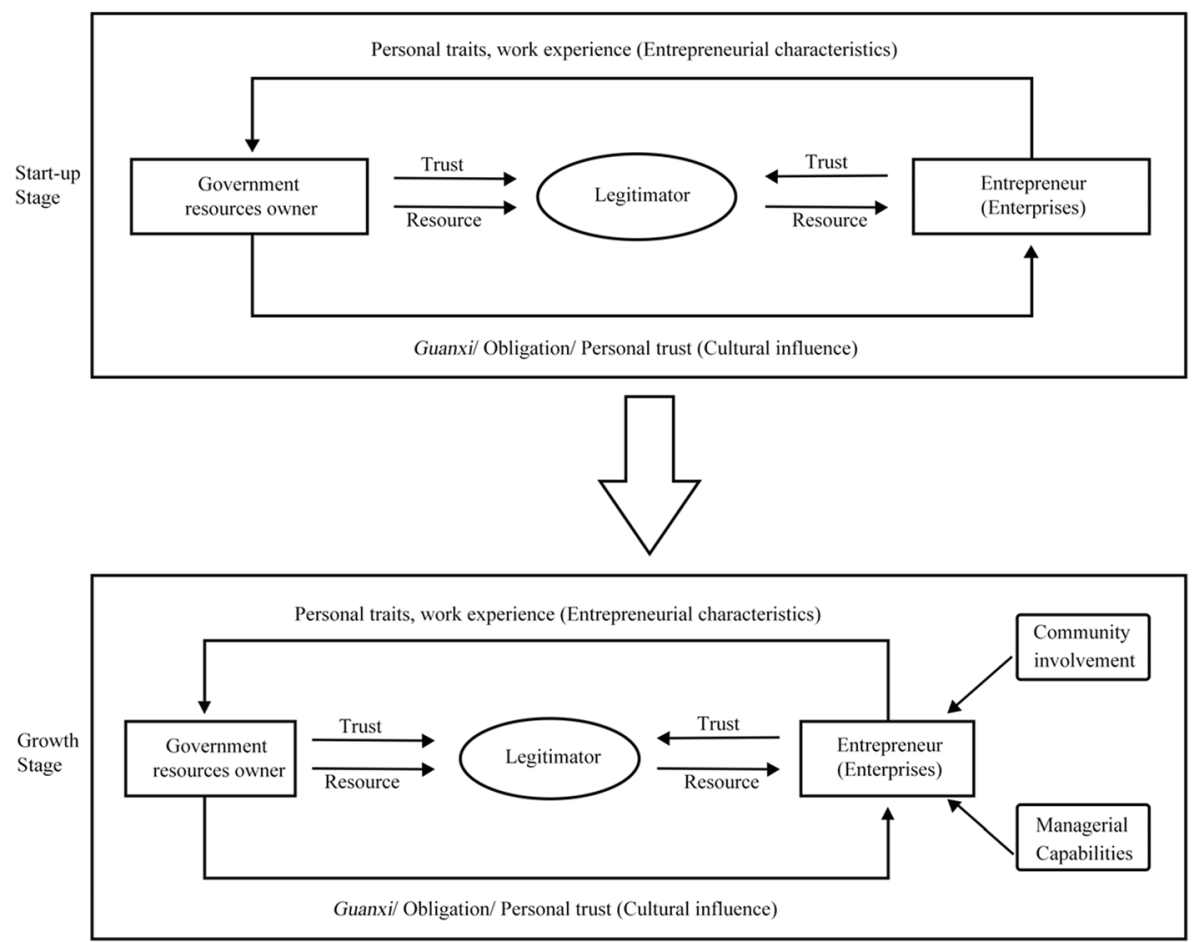

Fig. 6 The process of cronyism in China

stage and sustain growth in terms of acquiring scale, acquiring more resources, and gaining access to markets, it was found that cronyism remained important. To survive the transition from the early stages to further growth, firms rely on the benefits derived from their networks (Peng \& Zhou, 2005), and since these networks are now well established, the speed at which exchanges can happen or access can be granted assist the entrepreneur in developing a competitive advantage. The impact of the relationship can also have a wider influence, adding value to the wider community.

When the enterprise enters a growth stage, entrepreneurs' attention was more likely to focus on community involvement and the build-up of managerial capability. The three enterprises involved their local communities at different levels. Two cases only gave short-term or one-off financial benefits to communities related to business transactions, while the third had a sustainable strategy. This confirms that involving communities successfully can promote sustainable development (Abbott, 2013: 4). Stone (1989: 207) notes that community participation involves designing "development in such a way that intended beneficiaries are encouraged to take matters into their own hands, to participate in their own resources, [by] defining their own needs and making their own decision about how to meet them."

Cronyism complements the modern corporate governance structure in the growth stage. As Yang's Property showed, cronyism can be mutually beneficial when all parties involved receive benefits; nepotism is efficient for the group when the person 
from the community can generate more returns for the group than a high-performing outsider. When discussing cronyism, researchers tend to focus on situations where cronyism is abused or when managers award a contract to an incompetent friend (Jaskiewicz et al., 2013; Khatri et al., 2003; Zhang \& Gill, 2019). Cronyism can be responsible cronyism if it involves the community's interest. For example, Hooker (2009) explains that responsible cronyism happens when managers favor friends because they trust them to do a good job. It could assist in developing a competitive advantage, securing community involvement and support, enhancing the speed at which these developments can take place, and supplementing the efforts to reach a higher-order impact. This leads to our final proposition:

Proposition 3 During the growth stage, cronyism and guanxi remain important, but strategic community involvement leads to sustained access to critical resources.

This research shows that cronyism can be utilized in different ways to acquire different resources. This leads to benefits for both parties involved in cronyism but could also benefit the wider community. The reciprocal relationship then also involves a social value. During the growth stages, entrepreneurs combine managerial capabilities and cronyism tend to have better performance than those relying on cronyism. Entrepreneurs should develop guanxi with the community without any utilitarian purpose. This finding is relevant to the ongoing debate about formality and informality being complementary (Cardinal et al., 2004; Li, 2007) or substitutive (Peng, 2003). Researchers conclude it is imperative to have a proper balance between formal rule and informal norm (Helmke \& Levitsky, 2004; Li, 2005; Li, 2007). Social capital should be promoted if it does not seek private interest at the expense of public interest in terms of economic efficiency and social justice ( $\mathrm{Li}, 2007)$.

\section{Contributions}

This research contributes to theory and practice. Our research contributes to a better understanding of how entrepreneurs in the context of China's property development industry utilize their networks, especially the practice of cronyism, to acquire resources. Our study contributes to theory by piecing together a model that draws on guanxi literature and offers new propositions relating to the behavior patterns surrounding business relationships in a Chinese context. This research is in line with the increasing need for process-oriented research in guanxi literature (Li et al., 2019).

We have specified two contingency working mechanisms for cronyism practice: the entrepreneurial characteristics and the stage of enterprise. This research responds to the lack of dynamic knowledge about guanxi even though current studies on the topic have produced fruitful results ( $\mathrm{Li}$ et al., 2019). This research also contributes to a better understanding of the foundation for the use of cronyism and the contextual influences and interpretations (Leung \& Barnes, 2020).

This research has practical contributions for both local and foreign entrepreneurs. As previously noted (Leung \& Barnes, 2020), foreign managers always 
perceive cronyism as unethical. This disadvantages them when negotiating in China. This study highlights how cronyism can be practiced to acquire resources; entrepreneurs could learn to nurture ethical cronyism to obtain resources legally and enhance corporate performance. This study also highlights the fact that businesses can benefit from community involvement. Businesses should consider the welfare of more stakeholders, which could potentially benefit firms in acquiring resources. Having this better understanding of cronyism in different cultural contexts can also assist in developing cultural intelligence.

\section{Limitations}

This article is limited to the extent that it only researches firms from a single industry in China. While the case enterprises used may not reflect all Chinese firms, the findings from these cases could be extended to other regions and industries. The choice of this dynamic industry was made because of its unique and increasing economic contribution. Three in-depth case studies were chosen because quantitative research will not inform readers about the relationships in such an industry because they are complex in their uniqueness. They may form a "geographical and industry-specific sub-culture" (Jukka et al., 2017), thus limiting how our findings can be applied to other industries. Future studies can sample enterprises from different industries to examine the impacts of cronyism on firm performance in different industries and national settings. Second, the findings are based on case studies from a single emerging economy: China. However, cronyism is a universal phenomenon, especially across emerging economies; future research could study cronyism in other emerging economies or other industries' institutions.

\section{Conclusion}

We note that our research has significance as existing research focuses on the negative outcomes of cronyism and lacks process-oriented research on how cronyism influences entrepreneurship and resource acquisition. In particular, the Chinese context is different from its Western counterpart. This study proposed two contingency working mechanisms for cronyism: the entrepreneurial characteristics and a staged model. Therefore, we investigated the use of cronyism to obtain resources in the start-up and growth stages of China's private property development enterprises. Our investigation shows how during the start-up stage, enterprises obtain both information and particular resources through their crony resource owners directly. During the growth stages, the path changes, as some enterprises, focusing on developing core competence, obtain resources from resource owners as a result of their reputation and through community involvement. This research contributes to entrepreneurship and cronyism literature by providing a contextualized understanding of the concept and process of using cronyism in different firm growth stages. 


\section{Appendix}

Table 3 The process of cronyism practice

\begin{tabular}{|c|c|c|c|c|}
\hline Case & Quotes & $\begin{array}{l}\text { First-order } \\
\text { concepts }\end{array}$ & $\begin{array}{l}\text { Second-order } \\
\text { themes }\end{array}$ & $\begin{array}{l}\text { Aggregate } \\
\text { dimensions }\end{array}$ \\
\hline \multirow[t]{3}{*}{1} & $\begin{array}{l}\text { "Guang Yang's persistence in assisting } \\
\text { Yang was an important factor; however, } \\
\text { Yang himself was patient in the face of } \\
\text { hardship." }\end{array}$ & Being persistent & Personal traits & $\begin{array}{l}\text { Emphasis on } \\
\text { entrepreneur }\end{array}$ \\
\hline & $\begin{array}{l}\text { "Guang Yang and Yang were the kinds of } \\
\text { friends that were worth my emotional } \\
\text { investment and help." }\end{array}$ & $\begin{array}{l}\text { Worth trust and } \\
\text { help }\end{array}$ & Worth trust & $\begin{array}{l}\text { Cultural } \\
\text { influence }\end{array}$ \\
\hline & $\begin{array}{l}\text { "Yang gradually accumulated market } \\
\text { knowledge through his personal } \\
\text { development and work experience. It } \\
\text { shows the process of Yang's transition }\end{array}$ & $\begin{array}{l}\text { Gradually } \\
\text { understand } \\
\text { the market } \\
\text { operation }\end{array}$ & $\begin{array}{l}\text { Accumulation of } \\
\text { market } \\
\text { knowledge }\end{array}$ & $\begin{array}{l}\text { Emphasis on } \\
\text { entrepreneur }\end{array}$ \\
\hline
\end{tabular}

from a normal villager, moving to a

developed central district (Baojiang

District), being exposed to business

activities, to working at several

management positions in Century

Group, a large SOE."

"Guang Yang used his network with other property developers in [Local City]. To make Yang and Guang Yang's

collaboration less obvious and less sensitive, Guang Yang discussed the project with his old friend $\mathrm{Ma}$, the owner of Harmony Property, and invited Ma to be the nominal developer for the reconstruction project."

"I implemented some strategies to encourage these former residents to accept the changes calmly. I offered a price lower than the market price to the former residents who wanted to purchase a unit in B100. This was RMB1,400/sq. m (US\$223/sq. m), which was RMB 300/sq. m (US\$ 48/sq. $\mathrm{m})$ lower than the market price. This strategy of offering an attractive price worked, as almost all the residents purchased new units in B100."

"Although I have maintained a fairly good personal relationship with Duan, I should not have used his wife as the designer, blindly. Duan's wife was a designer for projects such as factory buildings. She had no experience in designing such commercial buildings as a specialized wholesale market."

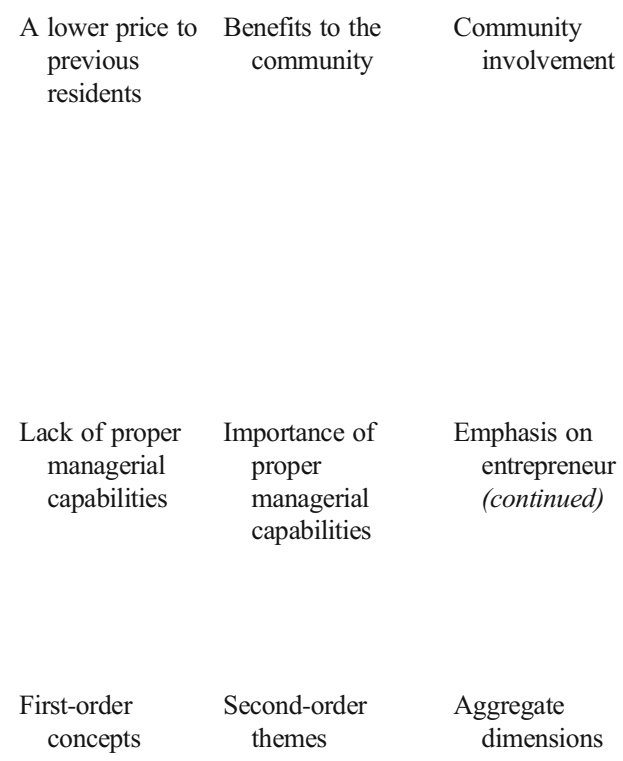

A facilitator of Legitimator Legitimator
the
transaction

(1)


Table 3 (continued)

\begin{tabular}{|c|c|c|c|c|}
\hline Case & Quotes & $\begin{array}{l}\text { First-order } \\
\text { concepts }\end{array}$ & $\begin{array}{l}\text { Second-order } \\
\text { themes }\end{array}$ & $\begin{array}{l}\text { Aggregate } \\
\text { dimensions }\end{array}$ \\
\hline 2 & $\begin{array}{l}\text { "I selected Tang as my assistant in XBI, as } \\
\text { I thought that Tang was a skilled } \\
\text { member of staff. More importantly, I } \\
\text { attached great importance to the personal }\end{array}$ & $\begin{array}{l}\text { Being moral } \\
\text { High levels of } \\
\text { skills }\end{array}$ & $\begin{array}{l}\text { Moral standards } \\
\text { Level of skills }\end{array}$ & $\begin{array}{l}\text { Cultural } \\
\text { influence } \\
\text { Emphasis on } \\
\text { entrepreneur }\end{array}$ \\
\hline
\end{tabular}

traits of my subordinates. I believed that

Tang was an impartial person.

Therefore, Tang should be able to have a

sound judgment towards issues arising

during the development of XBI."

"Jiao and Tang provided the client with the feasibility report within just one week, compared to the three to four weeks for finishing feasibility reports other competitors needed."

"Although I had a very good personal relationship with the Director-General, she asked me not to be involved in this issue. To help Jiao and Tang obtain the legal land certificate, I said to the Director-General that 'I had some shares in this project,' though I did not. Then, the Director-General said to me, 'You should have told me earlier'."

"In addition to the 43 residential buildings constructed for the villagers, Wisdom Property also provided means of production to villagers in Gold Village in the following two ways. Firstly, Wisdom Property designed commercial units in the Gold Garden project, but instead of selling or renting to the public at RMB 600/month (US\$94/month).

Second, Wisdom Property built a building suitable for retail premises for Gold Village and invited a famous department store into this building. Villagers collectively owned $70 \%$ of the profit and the village committee owned the remaining 30\%."

“Company Document No. 11 provided additional provisions to the initial customer service management standards. It detailed the responsibilities of the Customer Service Department and work procedures to eliminate the unclear work division between the Customer Service Department and the Maintenance Department."

Case Quotes

Methods to help villagers

A facilitator
the
transaction

Legitimator

More sustainable the community
More detailed company management

\section{Managerial capabilities}

First-order concepts

Being persistent
Second-order themes

Personal traits ways to benefit
Legitimator

Community

\section{Legitimator} involvement

Emphasis on entrepreneur

e in the industry -

3 "I see the military experience as important in maturing individuals and developing 
Table 3 (continued)

\begin{tabular}{llll}
\hline Case Quotes & $\begin{array}{l}\text { First-order } \\
\text { concepts }\end{array}$ & $\begin{array}{l}\text { Second-order } \\
\text { themes }\end{array}$ & $\begin{array}{l}\text { Aggregate } \\
\text { dimensions }\end{array}$ \\
\hline
\end{tabular}

capacities that are useful in their later life."

'Kong's first position was as an administration officer specializing in land management in Station Sub-district Office of [Local City]. This position not only provided him with the advantages of being a public servant, but it also enabled Kong for the first time to learn about the property development industry and its regulatory procedures."

“... If Childer Village wanted to construct a building, they needed to borrow Childer Village Property's certificate. When the buildings were completed, Childer Village Property could then transfer the ownership to Childer Village."

"An important reason to privatize Childer Village Property was to resolve the serious loss in Childer Village's other collective firms, such as the electric motor firm and maintenance firm. As a condition attached to the privatization of Childer Village Property, Han asked me to bear a debt of RMB 500,000."

"The problem this created became more obvious in Kong's later project,

Continental project, in which he was cheated by his business partner and was involved in three lawsuits."

$\begin{array}{llr}\begin{array}{c}\text { Learned more } \\ \text { about the }\end{array} & \begin{array}{c}\text { Accumulation of } \\ \text { market }\end{array} & \begin{array}{c}\text { Emphasis on } \\ \text { entrepreneur }\end{array} \\ \text { industry } & \text { knowledge } & \end{array}$

A facilitator of Legitimator
the
transaction
$\begin{gathered}\text { Being beneficial Being beneficial to Community } \\ \text { to the village } \\ \text { the community involvement }\end{gathered}$

Open Access This article is licensed under a Creative Commons Attribution 4.0 International License, which permits use, sharing, adaptation, distribution and reproduction in any medium or format, as long as you give appropriate credit to the original author(s) and the source, provide a link to the Creative Commons licence, and indicate if changes were made. The images or other third party material in this article are included in the article's Creative Commons licence, unless indicated otherwise in a credit line to the material. If material is not included in the article's Creative Commons licence and your intended use is not permitted by statutory regulation or exceeds the permitted use, you will need to obtain permission directly from the copyright holder. To view a copy of this licence, visit http://creativecommons.org/licenses/by/4.0/.

\section{References}

Abbott, J. 2013. Sharing the city: Community participation in urban management. London: Taylor and Francis.

Adler, P. S., \& Kwon, S.-W., 2002. Social capital: Prospects for a new concept. The Academy of Management Review, 27: 17-40. https://doi.org/10.2307/4134367

Alon, I. 2003. Chinese culture, organizational behavior, and international business management. Westport: Greenwood. 
Anand, N., Gardner, H. K., \& Morris, T. 2007. Knowledge-based innovation: Emergence and embedding of new practice areas in management consulting firms. The Academy of Management Journal, 50(2): 406428.

Andrews, T. G., Nimanandh, K., Htun, K. T., Kantabutra, S., 2019. Responsible cronyism in transition: Understanding changing attitudes to business corruption in Myanmar. Asia Pacific Business Review, 117.

Arasli, H., \& Tumer, M. 2008. Nepotism, favoritism and cronyism: A study of their effects on job stress and job satisfaction in the banking industry of North Cyprus. Social Behavior and Personality, 36: 12371250.

Atuahene-Gima, K., \& Li, H. 2002. When does trust matter? Antecedents and contingent effects of supervisee trust on performance in selling new products in China and the United States. Journal of Marketing, 66: 61-81.

Begley, T. M., Khatri, N., \& Tsang, E. W. K. 2010. Networks and cronyism: A social exchange analysis. Asia Pacific Journal of Management, 27(2): 281-297.

Blaikie, N. W. H. 2000. Designing social research: The logic of anticipation. Cambridge: Polity Press.

Brush, C. G., Greene, P. G., \& Hart, M. M. 2001. From initial idea to unique advantage: The entrepreneurial challenge of constructing a resource base. Academy of Management Executive, 15(1): 64-78.

Cadman, D., \& Topping, R. 1995. Property development. London: Taylor \& Francis.

Cardinal, L. B., Sitkin, S. B., \& Long, C. P. 2004. Balancing and rebalancing in the creation and evolution of organizational control. Organization Science, 15(4): 411-431.

Chu, Z., Wang, Q., Lai, F. \& Collins, B. J., 2019. Managing interdependence: Using Guanxi to cope with supply chain dependency. Journal of Business Research, 103: 620-631.

Cingoz, A., \& Akilli, H. S. 2015. A study on examining the relationships among cronyism, self-reported job performance, and organizational trust. In The 2015 WEI International Academic Conference Proceedings. Vienna, Austria.

Collins English Dictionary and Thesaurus. 2000. 2nd edn. London: Collins.

Corbin, J., \& Strauss, A., 2014. Basics of qualitative research: Techniques and procedures for developing grounded theory. Thousand Oaks, Calif.: SAGE Publications.

Cousin, V. 2011. Banking in China. 2nd edn. New York: Palgrave Macmillan.

Creswell, J. W. (Ed.) 2007. Chapter 4: Five qualitative approaches to inquiry. In Qualitative inquiry and research design: Choosing among five approaches: 69-110. Thousand Oaks, Calif.: SAGE Publications.

Edelman, L. F., Manolova, T., Shirokova, G., \& Tsukanova, T. 2016. The impact of family support on young entrepreneurs' start-up activities. Journal of Business Venturing, 31(4), 428-448.

Eisenhardt, K. M. 1989. Building theories from case study research. The Academy of Management Review, 14(4): 532-550.

Eisenhardt, K. M., \& Graebner, M. E. 2007. Theory building from cases: Opportunities and challenges. The Academy of Management Journal, 50(1): 25-32.

El-Said, H., \& Harrigan, J. 2009. You reap what you plant: Social networks in the Arab world - The Hashemite Kingdom of Jordan. World Development, 37(7): 1235-1249.

Enderwick, P. 2005. What's bad about crony capitalism? Asian Business \& Management, 4(2): 117-132.

Furlan, A., Grandinetti, R., \& Paggiaro, A. 2014. Unveiling the growth process: Entrepreneurial growth and the use of external resources. International Journal of Entrepreneurial Behavior \& Research, 20: 20-41.

Gao, C., Zuzul, T., Jones, G., \& Khanna, T. 2017. Overcoming institutional voids: A reputation-based view of long-run survival. Strategic Management Journal, 38: 2147-2167.

Gioia, D. A., Corley, K. G., \& Hamilton, A. L. 2013. Seeking qualitative rigor in inductive research: Notes on the Gioia methodology. Organizational Research Methods, 16: 15-31.

Glaser, B. G. 1978. Theoretical sensitivity: Advances in the methodology of grounded theory. Mill Valley: Sociology Press.

Glaser, B. G., \& Strauss, A. L. 1967. The discovery of grounded theory: Strategies for qualitative research. Chicago: Aldine Publishing.

Greene, S. 2004. Social identity theory and party identification. Social Science Quarterly, 85(1): 136-153.

Greve, A., \& Salaff J. W. 2003. Social networks and entrepreneurship. Entrepreneurship Theory and Practice, 27: $1-22$.

Gummesson, E. 2007. "Access to reality: observations on observational methods", Qualitative Market Research, 10(2): 130-134.

Guo, C., \& Miller, J. K. 2010. Guanxi dynamics and entrepreneurial firm creation and development in China. Management and Organization Review, 6(2): 267-291.

Hallen, B. L., \& Eisenhardt, K. M. 2012. Catalyzing strategies and efficient tie formation: How entrepreneurial firms obtain investment ties. Academy of Management Journal, 55(1): 35-70. 
Harper, M., \& Cole, P. 2012. Member checking: Can benefits be gained similar to group therapy? The Qualitative Report, 17(2): 510-517.

Helmke, G. \& Levitsky, S., 2004. Informal institutions and comparative politics: A research agenda. Perspectives on Politics, 2(4): 725-740.

Hong, C. 2011, September. Is cronyism always negative? A model of organizational appointment based on structure of Guanxi. In Management Science and Engineering (ICMSE), 2011 International Conference: 532-537. IEEE.

Hooker, J. 2009. Corruption from a cross-cultural perspective. Cross Cultural Management: An International Journal, 16(3): 251-267.

Horak, S., Afiouni, F., Bian, Y., Ledeneva, A., Muratbekova-Touron, M., \& Fey, C., 2018. Management and organization review special issue 'social networks-the dark and bright sides of informal networks'. Management and Organization Review, 14(3): 641-646.

Hoskisson, R. E., Eden, L., Lau, C. M., \& Wright, M. 2000. Strategy in emerging economies. The Academy of Management Journal, 43(3): 249-267.

Hsu, J. Y., \& Saxenian, A. 2000. The limits of guanxi capitalism: Transnational collaboration between Taiwan and the USA. Environment and Planning A, 32(11): 1991-2005.

Huang, X., Van der Vliert, E., \& Van der Vegt, G. 2005. Breaking the silence culture: Stimulation of participation and employee opinion withholding cross-nationally. Management and Organization Review, 1(3): 459-482.

Hudson, S., \& Claasen, C. 2017. Nepotism and cronyism as a cultural phenomenon? In The handbook of business and corruption: Cross-sectoral experiences: pp. 95-118. Emerald Publishing Limited.

Jaskiewicz, P., Uhlenbruck, K., Balkin, D. B., \& Reay, T. 2013. Is nepotism good or bad? Types of nepotism and implications for knowledge management. Family Business Review, 26(2): 121-139.

Jukka, M., Blomqvist, K., Li, P. P., \& Gan, C. 2017. Trust-distrust balance: Trust ambivalence in SinoWestern B2B relationships. Cross Cultural \& Strategic Management, 24: 482-507.

Kang, D. C. 2003. Transaction costs and crony capitalism in East Asia. Comparative Politics, 35(4): $439-458$.

Kellermanns, F., Walter, J., Crook, T. R., Kemmerer, B., \& Narayanan, V. 2016. The resource-based view in entrepreneurship: A content-analytical comparison of researchers' and entrepreneurs' views. Journal of Small Business Management, 54(1): 26-48.

Khan, N. U., Li, S., Safdar, M. N. \& Khan, Z. U. 2019. The role of entrepreneurial strategy, network ties, human and financial capital in new venture performance. Journal of Risk and Financial Management, 12(1): 41.

Khanna, T., \& Palepu, K. G. 2010. Winning in emerging markets: A road map for strategy and execution. Boston: Harvard Business Review Press.

Khanna, T., \& Rivkin, J. W. 2001. Estimating the performance effects of business groups in emerging markets. Strategic Management Journal, 22, 45-74.

Khatri, N., \& Tsang, E. W. K. 2003. Antecedents and consequences of cronyism in organizations. Journal of Business Ethics, 43(4): 289-303.

Khatri, N., Tsang, E. W. K., \& Begley, T. M. 2003. Cronyism: The downside of social networking. Academy of Management Proceedings, (1): C1-C6.

Khatri, N., Tsang, E. W. K., \& Begley, T. M. 2006. Cronyism: A cross-cultural analysis. Journal of International Business Studies, 37(1): 61-75.

Khatri, N., Tsang, E. W., \& Begley, T. M. 2016. Cronyism: A cross-cultural analysis. In Crony Capitalism in India: 33-58. London: Palgrave Macmillan.

Krefting, L. 1991. Rigor in qualitative research: The assessment of trustworthiness. American Journal of Occupational Therapy, 45(3): 214-222.

Krug, B., \& Hendrischke, H. 2003. The economics of corruption and cronyism-An institutional approach to the reform of governance. In J. B. Kidd \& F. J. Richter (Eds.). Corruption and governance in Asia: 131148. London: Palgrave Macmillan.

Kwock, B., James, M. X., \& Tsui, A. S. C. 2013. Doing business in China: What is the use of having a contract? The rule of law and guanxi when doing business in China. Journal of Business Studies Quarterly, 4(4): 56-67.

Lee, D.Y. \& Tsang, E.W., 2001. The effects of entrepreneurial personality, background and network activities on venture growth. Journal of Management studies, 38(4): 583-602.

Leung, T. K. P., Heung, V. C. S., \& Wong, Y. H. 2008. Cronyism: One possible consequence of guanxi for an insider: How to obtain and maintain it? European Journal of Marketing, 42: 23-34.

Leung, T.K.P., \& Barnes, B.R., 2020. Ethical cronyism: An insider approach for building guanxi and leveraging business performance in China. Asia Pacific Business Review, 26(2): 124-148.

Leung, W. 2010. Real estate market issues in China: Guest editor's introduction. Chinese Economy, 43(2): 3-4. 
Li, H., \& Zhang, Y. 2007. The role of managers' political networking and functional experience in new venture performance: Evidence from China's transition economy. Strategic Management Journal, 28(8): 791-804.

Li, P.P., 2005. The puzzle of China's township-village enterprises: The paradox of local corporatism in a dualtrack economic transition. Management and Organization Review, 1(2): 197-224.

Li, P.P., 2007. Social tie, social capital, and social behavior: Toward an integrative model of informal exchange. Asia Pacific Journal of Management, 24(2): 227-246.

Li, P.P., 2008. Toward a geocentric framework of trust: An application to organizational trust. Management and Organization Review, 4(3): 413-439.

Li, P.P., 2009. The duality of crony corruption in economic transition: Toward an integrated framework. Journal of Business Ethics, 85(1): 41-55.

Li, P.P., Zhou, S.S., Zhou, A.J., Yang, Z., 2019. Reconceptualizing and redirecting research on Guanxi: 'Guan-Xi' interaction to form a multicolored Chinese knot. Management and Organization Review, 15(3): 643-677.

Lin, J. \& Si, S.X., 2010. Can guanxi be a problem? Contexts, ties, and some unfavorable consequences of social capital in China. Asia Pacific Journal of Management, 27: 561-581.

Loewe, M., Blume, J., Schönleber, V., Seibert, S., Speer, J., \& Voss, C. 2007. The impact of favouritism on the business climate: A study on wasta in Jordan. Deutsches Institut für Entwicklungspolitik.

Luo, Y. \& Chen, M. 1997. Does guanxi influence firm performance? Asia Pacific Journal of Management, 14(1): 1-16.

Luo, Y., Huang, Y., \& Wang, S. L. 2012. Guanxi and organizational performance: A meta-analysis. Management and Organization Review, 8(1): 139-172.

Marion, T.J., Eddleston, K.A., Friar, J.H. \& Deeds, D. 2015. The evolution of interorganizational relationships in emerging ventures: An ethnographic study within the new product development process. Journal of Business Venturing, 30(1): 167-184.

Meuer, J., \& Krug, B. 2011. Chapter 7: The current state of research on networks in China's business system. In W. Pascha, C. Storz, \& M. Taube (Eds.). Institutional variety in east Asia: Formal and informal patterns of coordination: 145-167. Cheltenham: Edward Elgar.

Miller N. J, Besser T., \& Malshe A. 2007. Strategic networking among small businesses in small US communities. International Small Business Journal, 25(6): 631-665.

Mitchell, M. D., Eastman, S. \& Winter, T. 2019. A culture of favoritism: Corporate privilege and beliefs about markets and government. Mercatus Research Paper. Available at SSRN: https://ssrn.com/abstract= 3361035 or https://doi.org/10.2139/ssrn.3361035

Naughton, B. 1999. China's transition in economic perspective. In M. Goldman, \& R. MacFarquhar (Eds.). The paradox of China's post-Mao reforms: 30-44. Cambridge: Harvard University Press.

Obstfeld, D., Borgatti, S.P. \& Davis, J. 2014. Brokerage as a process: Decoupling third party action from social network structure. In Contemporary perspectives on organizational social networks. Emerald Group Publishing Limited. Pp. 135-159.

Pearce, J. L. 2015. Cronyism and nepotism are bad for everyone: The research evidence. Industrial and Organizational Psychology, 8: 41-44.

Peng, M. W. 2003. Institutional transitions and strategic choices. The Academy of Management Review, 28(2): 275-296.

Peng, M. W., \& Zhou, J. Q. 2005. How network strategies and institutional transitions evolve in Asia. Asia Pacific Journal of Management, 22(4): 321-336.

Poncet, S., Steingress, W., \& Vandenbussche, H. 2010. Financial constraints in China: Firm-level evidence. China Economic Review, 21(3): 411-422.

Redding, G. 2002. The capitalist business system of China and its rationale. Asia Pacific Journal of Management, 19(2): 221-249.

Redding, G. 2008. Separating culture from institutions: The use of semantic spaces as a conceptual domain and the case of China, Management and Organization Review, 4(2): 257-289.

Ridder, H. G., 2017. The theory contribution of case study research designs. Business Research, 10: 281-305.

Risjord, M. 2014. Philosophy of social science: A contemporary introduction. New York: Routledge.

Root, M. 2000. How we divide the world. Philosophy of Science, 67: S628-S639.

Salter, M. S. 2014. Crony capitalism, American style: What are we talking about here? Edmond J. Safra Research Lab Working Papers No. 50, Harvard University, Cambridge.

Sandefur, R. L., \& Laumann, E. O. 1998. A paradigm for social capital. Rationality and Society, 10, 481-501. https://doi.org/10.1177/104346398010004005.

Shane, S. A. 2003. A general theory of entrepreneurship: The individual-opportunity nexus. Cheltenham: Edward Elgar Publishing.

Smith, D., \& Sutter, D. 2012. Gauging the perception of cronyism in the United States. Mercatus Center. 
Soleimanof, S. 2016. Cronyism and entrepreneurship: An international analysis of the influence of cronyism on country level productive and unproductive entrepreneurship (Doctoral dissertation). Oklahoma State University. Accessed at: https://shareok.org/handle/11244/48873

Stake, R. 1995. The art of case study research. Thousand Oaks: Sage Publications.

Stevenson, A. 2010. Oxford Dictionary of English. Oxford Univesity Press. DOI: https://doi.org/10.1093/ acref/9780199571123.001.0001

Stone, L. 1989. Cultural crossroads of community participation in development: A case from Nepal. Human Organization, 48(3): 206-213.

Su, C., \& Littlefield, J. E. 2001. Entering guanxi: A business ethical dilemma in mainland China? Journal of Business Ethics, 33: 199-210.

$\mathrm{Su}$, W., \& Lee, C. 2013. Effects of corporate governance on risk taking in Taiwanese family firms during institutional reform. Asia Pacific Journal of Management, 30(3): 809-828.

Tonoyan, V., Strohmeyer, R., Habib, M., Perlitz, M. 2010. Corruption and entrepreneurship: How formal and informal institutions shape small firm behavior in transition and mature market economies. Entrepreneurship Theory and Practice, 34(5): 803-831.

Tsai, S. 2002. Back-alley banking: Private entrepreneurs in China. New York: Cornell University Press.

Turan, A. 2015. Does the perception of organizational cronyism lead to career satisfaction or frustration with Work? The mitigating role of organizational commitment. Research in Applied Economics, 7(3): 14-30.

Turhan, M. 2014. Organizational cronyism: A scale development and validation from the perspective of teachers. Journal of Business Ethics, 123(2): 295-308.

Walder, A. G. 2002. Markets and income inequality in rural China: Political advantage in an expanding economy. American Sociological Review, 67: 231-253.

Wang, A. C., Chiang, J. T. J., Chou, W. J., \& Cheng, B.-S. 2017. One definition, different manifestations: Investigating ethical leadership in the Chinese context. Asia Pacific Journal of Management, 34: 505-535.

Wang, H., \& Wang, K. 2012. What is unique about Chinese real estate markets? Journal of Real Estate Research, 34: 275-289.

Weber, M. 2001. The Protestant ethic and the spirit of capitalism. New York: Routledge.

Westwood, R., Chan, A. \& Linstead, S. 2004. Theorizing Chinese employment relations comparatively: Exchange, reciprocity and the moral economy. Asia Pacific Journal of Management, 21(3): 365-389.

Wilkinson, S., Reed, R., \& Cadman, D. 2008. Property development. London: Routledge.

Wu, J., Song, J., \& Zeng, C. 2008. An empirical evidence of small business financing in China. Management Research News, 31(12): 959-975.

Xi, J. 2018. Presentation at seminar for private enterprises, http://jhsjk.people.cn/article/30377329, Accessed 20 December, 2018.

Xin, K. R., \& Pearce, J. L. 1996. Guanxi: Connections as substitutes for formal institutional support. The Academy of Management Journal, 39: 1641-1658.

Xu, L., McIver, R.P., Shan, Y.G., Wang, X., 2016. Governance and performance in China's real estate sector. Managerial Finance, 42(6): 585-603.

Yin, R. 2006. Case study research: Design and methods. Applied social research methods series. Thousand Oaks, London: Sage Publications.

Yin, R. 2009. Case study research: Design and methods (4th edition). United States of America: Sage Publications.

Yin-Wah, C. 2007. Chinese business networks and Chinese entrepreneurship: Myths and partial truths - A review essay. Sociology for Change: 189-208.

Zane, L. J., \& DeCarolis, D. M. 2016. Social networks and the acquisition of resources by technology-based new ventures. Journal of Small Business \& Entrepreneurship, 28: 203-221.

Zhai, X. 2011. The principles of Chinese guanxi: Time-space order, life desire and their changes. Beijing: Peking University Press.

Zhang, J. 2010. The problems of using social networks in entrepreneurial resource acquisition. International Small Business Journal: Researching Entrepreneurship, 28: 338-361.

Zhang, J., Gill, C., 2019. Leader-follower guanxi: an invisible hand of cronyism in Chinese management. Asia Pacific Journal Human Resources, 57: 322-344.

Zhu, Y., Wittmann, X., Peng, M. W. 2012. Institution-based barriers to innovation in SMEs in China. Asia Pacific Journal of Management, 29(4): 1131-1142.

Publisher's note Springer Nature remains neutral with regard to jurisdictional claims in published maps and institutional affiliations. 
Dr Junfan Yu (PhD, University of New South Wales) is an Assistant Lecturer at School of Business, University of New South Wales, Canberra, Australia. She teaches economics and management at both undergraduate and postgraduate levels. She has managed and taught courses such as Australia and World Economy and Managing in Global Context. Her research interests include entrepreneurship, networking, regional entrepreneurial development and indigenous research on Chinese management.

Dr Saskia De Klerk ( $\mathrm{PhD}$, North-West University) is a Senior Lecturer in International Business at the University of the Sunshine Coast, Queensland, Australia. She also holds an extraordinary position as Associate Professor at North-West University, South Africa. She is serving as topic editor and reviewer of several international reputed journals. She has successfully supervised $\mathrm{PhD}$ students from Australia, Sri Lanka, Zimbabwe, Zambia, South Africa, and Salzburg. She teaches International Business, Cross-Cultural Management, Entrepreneurship, and Innovation. Her research interests include networking, entrepreneurship, and regional entrepreneurial ecosystem development. Her research projects focus on mapping, developing, and advancing entrepreneurial and networking skills. She is interested in supporting this transitioning to entrepreneurship in Science, Technology, Engineering, the Arts, for Young people, women, immigrants, veterans, and other minority groups.

Professor Michael Hess (PhD, University of New South Wales). Michael Hess is a Visiting Professor at the School of Business, University of New South Wales, Canberra. He has long-term research interests in economic development and community participation as well as in business and labour history. He can be contacted at m.hess@adfa.edu.au. 